\title{
The effect of microbial proteases on the activity of matrix metalloproteinases and oxidative stress indicators in wound tissue of rats with experimental diabetes mellitus
}

\author{
O. I. Myronenko ${ }^{1}$, L. V. Natrus ${ }^{1}$, T. I. Panova ${ }^{1}$, S. V. Verevka ${ }^{2}$ \\ ${ }^{1}$ Bogomolets National Medical University \\ 13, Shevchenko Blvd., Kyiv, Ukraine, 01601 \\ ${ }^{2}$ State institution "O. S. Kolomiychenko Institute of Otolaryngology \\ Of National Academy of Medical Sciences of Ukraine" \\ 3, Zoologichna, Kyiv, Ukraine, 03057 \\ Lnatrus777@gmail.com
}

\begin{abstract}
Aim. To study the effect of microbial proteases on the activity of matrix metalloproteinases and oxidative stress indicators in wound tissue of rats with experimental diabetes mellitus (DM). Methods. Skin burns were induced in the animals without somatic pathology and with the background diabetes mellitus. DM was reproduced by a single injection of streptozotocin, $50 \mathrm{mg} / \mathrm{kg}$. The multi-enzyme proteolytic composition Pronase (Sigma-Aldrich, USA), obtained from the culture fluid of Streptomiceus griseus, was applied to the wound. The content of malonic dialdehyde (MDA), as well as the activities of catalase (CAT), superoxide dismutase (SOD), and glutathione (GSH) were measured on a spectrophotometer. The collagenolytic activity of matrix metalloproteinases (MMPs) of skin tissues was determined by enzymephoresis (gelatin zymography). Results. At the physiological wound healing, an application of the composition increased the activity of total MMPs in homogenate on days 3-14 of the healing process, which enhanced the formation of free radicals and the activity of antioxidant system to compensate tissue damage. Thus, the CAT, GSH and SOD levels were elevated on days 7, 14 and 21, respectively. In case of DM, an application of the composition enhanced the activity of MMPs on days 14-21, which improved the proteolytic degradation of extracellular matrix proteins in the state of excessive glycation and did not worsen oxidative homeostasis state in the wound. Conclusion. The use of exogenous proteases is appropriate to enhance proteolysis in tissues with predominance of glycated proteins in case of chronic hyperglycemia to ensure controlled proteolysis.
\end{abstract}

Ke yw ord s: streptozotocin-induced diabetes, burn wounds, oxidative stress, proteolysis, healing.

(C) 2020 O. I. Myronenko et al.; Published by the Institute of Molecular Biology and Genetics, NAS of Ukraine on behalf of Biopolymers and Cell. This is an Open Access article distributed under the terms of the Creative Commons Attribution License (http://creativecommons.org/licenses/by/4.0/), which permits unrestricted reuse, distribution, and reproduction in any medium, provided the original work is properly cited 


\section{Introduction}

Diabetic foot syndrome with soft tissue ulcers accounts for $25 \%$ of the diabetes mellitus (DM) cases [1]. It is the cause of $85 \%$ of extremities amputation cases in patients with DM. Pathogenesis of this complication is based on diabetic neuropathy, micro- and macroangiopathy of the vessels, chronic inflammation and persistent infectious process in chronic hyperglycemia state [2]. The composition of the extracellular matrix (ECM) is determined by the production and degradation of its components and regulated by the balance of matrix metalloproteinases (MMPs) and their tissue inhibitors (TIMPs) [3, 4]. In DM, there are positive correlations between the level of non-enzymatically glycated proteins (AGEs) and increased MMPs activity [5] with simultaneous inhibition of TIMPs [6]. Among different MMPs expressed in healing tissue, collagenases (MMP-1, MMP-8) and gelatinases (MMP-2, MMP-9) play important role because they eliminate degraded collagen. It contributes to the polarization of macrophages into anti-inflammatory M2-phenotype and activation of fibroblasts. But, on the other hand, excessive destruction of the extracellular matrix can disrupt cell migration during neoangiogenesis and re-epithelialization [7].

Substances that affect proteolytic activity in the wound (protease-capturing matrices, enzyme inhibitors, antibodies) are components of the comprehensive treatment of chronic wounds and ulcers [8]. Increased activity of MMPs in these types of wound has led to the development of their inhibitors (tetracycline antibiotics), collagen-containing applicators (as an alternative substrate for
MMPs), superabsorbents (zinc chelators) [9]. However, the treatment of chronic ulcers with non-specific MMPs inhibitors significantly delayed wound re-epithelialization [10]. Therefore, in our opinion, the ability to regulate/control MMPs activity can be a promising pathogenetic target for treatment of diabetic foot syndrome. Tissue damage activates MMPs system via increased formation of free radicals and/or their insufficient inactivation, via direct effect of superoxide radical on the allosteric center of enzymes and via activation of transcription factor NF- $\kappa \mathrm{B}$ and MMPs genes expression [11].

In chronic hyperglycemia, the tissue extracellular matrix proteins undergo modification due to the formation of advanced glycation end products (AGEs). Matrix AGEs increase oxidative stress through their signaling function. It includes the interaction with RAGE receptors, activation of NADP-oxidase and xanthine oxidase, which are powerful sources of reactive oxygen species (ROS). They contribute to pro-inflammatory and pro-thrombotic changes in the wound healing process, prolongation of its inflammatory stage [12].

We consider the application of exogenous proteases to be theoretically substantiated pharmacological approach to promote the cleavage of disintegration products in necrotic wound tissue (debridement), providing a substantial change in the microenvironment of resident connective tissue macrophages, fibroblasts and epithelial cells. At the same time, additional proteolysis must not destroy all "necessary"components of the extracellular matrix. Therefore, covalent immobilization of 
enzymes in hydrophilic nanoporous polymeric carrier is considered to be the most appropriate way to achieve as full proteolysis of soluble peptides of necrotic tissues as possible and to prevent autolysis of enzymes [13].

Objective: to study the effect of microbial proteases on the activity of matrix metalloproteinases and oxidative stress indicators in wound tissue of rats with experimental diabetes mellitus (DM).

\section{Materials and Methods}

96 male adult Wistar rats, weighing 180-220 g, without signs of somatic pathology were used for the study. All manipulations were carried out in compliance with bioethical standards of humane treatment of laboratory animals in accordance with international and national regulations, including the resolution of Bogomolets NMU Commission on Bioethics (N126, 13.11.2019).

DM modeling was reproduced by single intraperitoneal injection of streptozotocin (STZ) to animals in dosage of $50 \mathrm{mg} / \mathrm{kg}$. Evidence of hyperglycemia in a month was the level of glucose (Me [QI $\div \mathrm{QIII}]$ min-max): $12.35[11.2 \div 16.68](10.2-19.00) \mathrm{mmol} / \mathrm{L} \mathrm{com}-$ pared to $5.37[4.7 \div 5.9](4.2-6.6) \mathrm{mmol} / \mathrm{L}$ in control group of healthy rats. The level of glycated hemoglobin $\mathrm{HbAl}_{\mathrm{c}}$ was $7.8[6.9 \div 10.2]$ (6.9-12.2) \% compared to $4.4[3.8 \div 4.9]$ (3.6$5.2) \%$ in control group. During further observation, glucose level range was 9.6$15.24 \mathrm{mmol} / \mathrm{L}$ in rats with DM.

Burn modeling. The day before burn injury, rectangular area of body skin was depilated in rats. The next day, under ether anesthesia, two hot copper plates $(3.7 \times 4.5 \mathrm{~cm}$, $0.0052 \mathrm{~m}^{2}$ ) were symmetrically applied to exposed parts of the body at the same time for $10 \mathrm{~s}$. Before that, the plates were kept in boiling water $\left(100{ }^{\circ} \mathrm{C}\right)$ for $10 \mathrm{~min}$. The total area of skin burns was $18-20 \%$ of the body surface and corresponds to second-degree burn (dermal superficial type).

Laboratory animals were divided into four main groups of 24 rats in each one. The first and second groups consisted of non-diabetic rats, the third and fourth groups consisted of rats with DM. After burn injury, neutral base ointment applications (talc dissolved in water) were used in animals of the 1st (Contr) and 3rd (DM) groups. In the 2nd (ImPr) and 4th $(\mathrm{DM}+\mathrm{ImPr})$ groups, local applications of the ointment containing exogenous proteases were daily used, from 1 to 21 day of observation.

The study of wound healing was carried out in dynamics on days 3, 7, 14, 21 after burn injury: all groups were divided into 4 subgroups with 6 rats in each one. On selected periods, rats were decapitated after intraperitoneal injection of lethal dose of sodium thiopental. The materials for the study were strips of injured tissue $(1.5 \times 0.5 \mathrm{~cm})$, including central part of the wound and its edge with the adjacent skin.

The enzyme-containing composition protected by the Ukrainian patent for utility model No 105500 was used as polyspecific immobilized proteases [13]. The enzymatic component of the applied composition is represented by a multi-enzyme proteolytic complex Pronase (Sigma-Aldrich, USA), obtained from the culture fluid of Streptomiceus griseus [14]. Pronase contained at least ten proteolytic components: five serine-type proteases, two Zn-endopeptidases, two Zn-leucine aminopeptidases, and one $\mathrm{Zn}$-carboxypeptidase [15]. 
Frozen tissue specimens of skin regenerates ( $1 \mathrm{~g}$ of wet weight) were intensively grinded in the mortar in liquid nitrogen and then homogenated in ice-cold $50 \mathrm{mM}$ Tris- $\mathrm{HCl}$ buffer $(\mathrm{pH} 7.4)$, additionally containing $150 \mathrm{mM}$ $\mathrm{NaCl}, 0.1 \%$ SDS and $1 \%$ Triton X-100 and supplemented with proteases inhibitor cocktail (6.5 $\mu \mathrm{M}$ aprotinin, $1.5 \mu \mathrm{M}$ pepstatin $\mathrm{A}, 23 \mu \mathrm{M}$ leupeptin, $1 \mathrm{mM}$ phenylmethylsulfonyl fluoride, $5 \mu \mathrm{g} / \mathrm{ml}$ soybean trypsin inhibitor). Tissue/buffer ratio was 1:5 (m/v). After homogenisation, samples were sonicated for $60 \mathrm{~s}$ by ultrasonic disintegrator Sartorius (Labsonic ${ }^{\circledR}$ M, Göttingen, Germany) and centrifuged at $16,000 \mathrm{~g}$ for $45 \mathrm{~min}$ at $4{ }^{\circ} \mathrm{C}$. The total protein concentration in each supernatant was determined spectrophotometrically by Stoscheck method measuring absorbance at 260, 280, and $320 \mathrm{~nm}$. The samples were diluted $1: 1$ in non-reducing electrophoretic Laemmli Sample Buffer, frozen and stored at $-80{ }^{\circ} \mathrm{C}$ before analysis.

Levels of collagenolytic activity of matrix metalloproteinases (MMPs) in protein samples were determined by enzyme-phoresis (gelatin zymography) as described elsewhere [16]. Electrophoretic separation of proteins was performed under non-reducing conditions by gel electrophoresis in copolymer of polyacrylamide (PAAG) $(8 \%)$ and gelatin $(5 \mathrm{mg} / \mathrm{ml})$ in tris-glycine buffer ( $\mathrm{pH}$ 8.6) containing $0.1 \%$ SDS, at a voltage of $70 \mathrm{~V}$. After electrophoresis, the gels were washed twice for $30 \mathrm{~min}$ in cold $2.5 \%(\mathrm{v} / \mathrm{v})$ Triton X-100 to remove SDS, and then 5 times for $5 \mathrm{~min}$ in cold bidistilled water. After washing, gels were incubated overnight at $37{ }^{\circ} \mathrm{C}$ in developed $50 \mathrm{mM}$ tris- $\mathrm{HCl}$ buffer ( $\mathrm{pH}$ 7.6), containing $0.15 \mathrm{M} \mathrm{NaCl}, 5 \mathrm{mM} \mathrm{CaCl}_{2}, 1 \mathrm{mM} \mathrm{ZnCl}_{2}$, and $0.02 \%$ Tween-20. Zymograms were stained with $0.11 \%$ Coomassie Brilliant Blue R-250 (Merck Millipore, Germany) solution in $30 \%$ methanol and $10 \%$ acetic acid and destained in the same solution lacking Coomassie Blue. The final gel had a uniform blue background except those regions to which MMPs had migrated and cleaved the substrate. The gelatinolytic activities were identified as transparent bands against the background of Coomassie Blue-stained gelatine. Apparent molecular weights of MMP bands were identified with the use of the prestained broad-range standard proteins (Page Ruler TMPlus, Prestained Protein Ladder, cat. no. 26619, Lithuania). Resulting MMP bands were visualized and quantified densitometrically applying the TL-120 software (TotalLab Ltd., USA). The gelatinolytic activity in each sample was defined as the arbitrary optical density value (arbitrary units) [16].

In the regenerate tissue, the levels of catalase (CAT), superoxide dismutase (SOD), malondialdehyde (MDA) and glutathione (GSH) were measured by biochemical methods using spectrophotometer (analyzer SINNOWA BS-3000M) at wavelengths $410,340,523$ and $420 \mathrm{~nm}$, respectively. The SOD activity was calculated by the degree of inhibition of adrenaline autoxidation rate. MDA was estimated by its reaction with thiobarbituric acid. Glutathione content was determined by the level of thionitrophenyl anion formation after interaction between SH-group and nitrobenzoic acid.

Statistical data processing was performed using program IBM SPSS Statistics 23. Shapiro-Wilk's test, ANOVA analysis, Sheffe's and Dunnett's criteria were used. 


\section{Results}

Visual assessment of wounds did not reveal any significant difference between the animals without somatic pathology and in case of the composition applications (Fig. 1). Burn injury causes inflammation, which is manifested by hyperemia, swelling and infiltration, followed by scab formation on the wound surface. Signs of coagulation necrosis were detected on day 3 of observation. By the $14^{\text {th }}$ day, the wound was devoid of epithelial lining and covered with a scab and areas of fibrinoid tissue necrosis. On day 21 , the epithelialization of the damaged surface was observed, but the central zone remained without epithelial lining and was covered with a scab.

MMP_total is the activity of all collagenolytic proteases identified in the sample. The changes for MMP_2 are described separately, because this protease plays a major role in the processes of tissue regeneration during skin healing. An example of gelatinases migration of Contr group is given, where the track numbers correspond to each sample (Fig. 2). A certain dispersal of results is a consequence of individual differences between animals in each group.
The content of MMP_total significantly increased on day 14, but then reduced by the $21^{\text {st }}$ day (Fig. 2, 3). The Enzyme-containing composition additionally increased the content of MMP_total during first 14 days compared to Contr group the detected level was 12 times
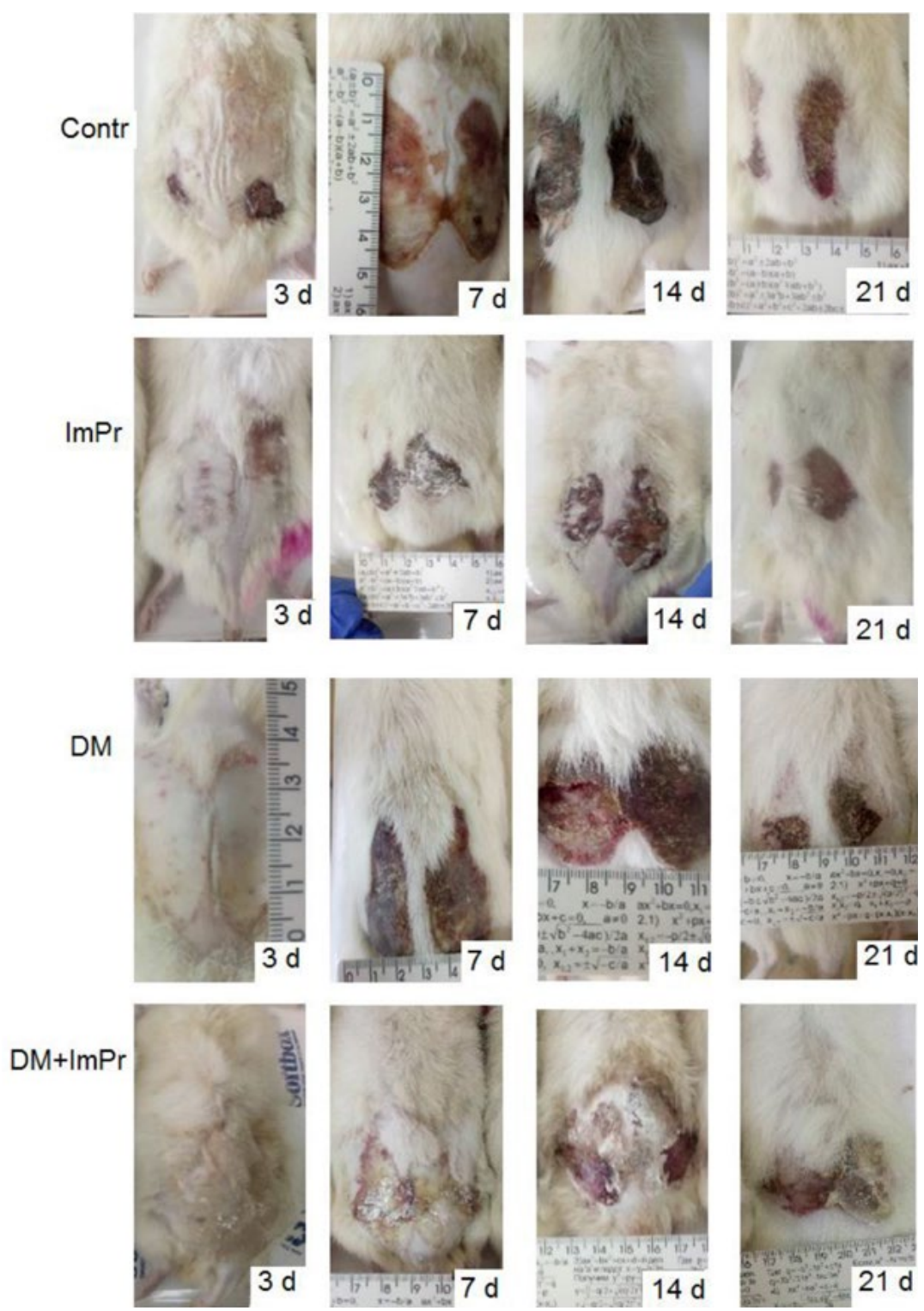

Fig. 1. Rats' burn wound appearance of the studied groups in the dynamics of healing (days 3,7,14,21 ) 
14 day

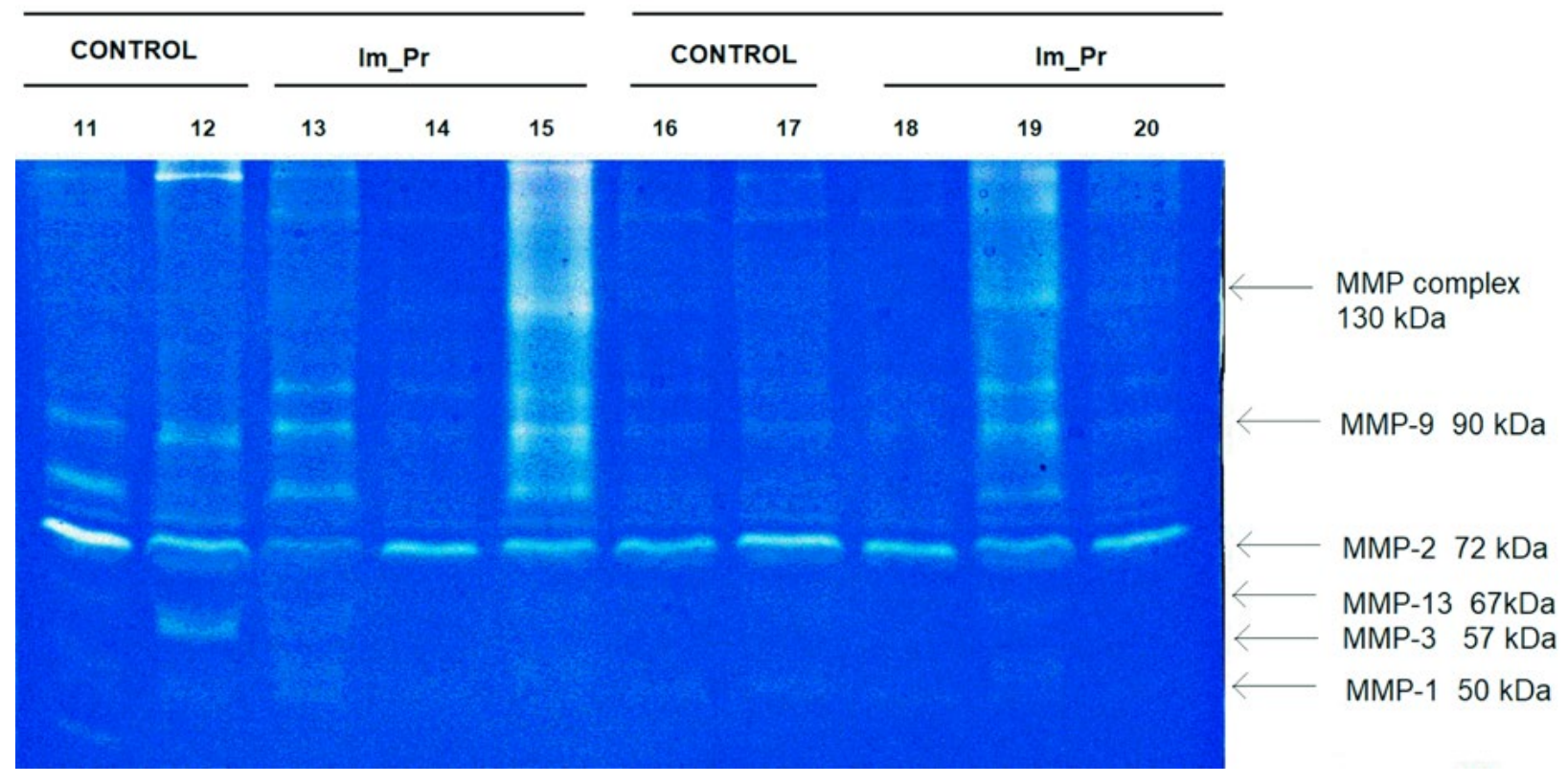

Fig. 2. The example zymogram - concentration-dependent MMP's gelatinase activity in skin tissue of rats on the 14-th and 21-th days of burn wound healing - at physiological healing process (Contr) and under the influence of exogenous immobilized proteases ( $\mathrm{ImPr}$ ), where the track numbers correspond to the animals markings.

higher on day $3(\mathrm{p}<0.01)$, and 4 times and 1.5 times higher on days 7 and $14(\mathrm{p}<0.01)$, respectively. The content of MMP_2 in Contr group increased up to 10 times on day 14 and reduced on day 21 . There was a 10 -fold increase of this indicator by the $21^{\text {st }}$ day in ImPr group. Application of the composition reduced the content of MMP_2 compared to Contr group, except for day 7, where the MMP_2 activity in ImPr group was higher than that in Contr group.

The effect of the enzyme-containing composition on the indicators of oxidative homeostasis (Fig. 4) showed that, according to the MDA level, the oxidative load was minimal on day 7 and maximal on day 14 of observation. At the same time, the application of com- position caused an MDA increase only on day 3 compared to the Contr group, but this indicator was lower in the ImPr group during other periods of observation.

The indicators of oxidative protection also increased on day 14 both during physiological healing and in case of applying the composition. In physiological wound healing, the activity of SOD decreased 6 times on day 7 and remained stable during other periods. Application of the composition decreased SOD level on days [3-7], but then increased it up to 2 times on day 21, compared to Contr group $(p<0.01)$, which reflects the role of SOD in prevention of oxidative stress with increasing biomass [17]. 
The activity of catalase was progressively increasing up to 10 times from 3 to 21 day during wound healing in Contr group. The composition application contributed to a greater increase in the level of catalase during all periods of observation. Thus, on day 7 , the indicator was 2 times higher in ImPr group, than in Contr group $(\mathrm{p}<0.01)$. The content of glutathione in Contr group was increasing from 3 to 14 day (up to 4 times), but with
$\boldsymbol{A}$

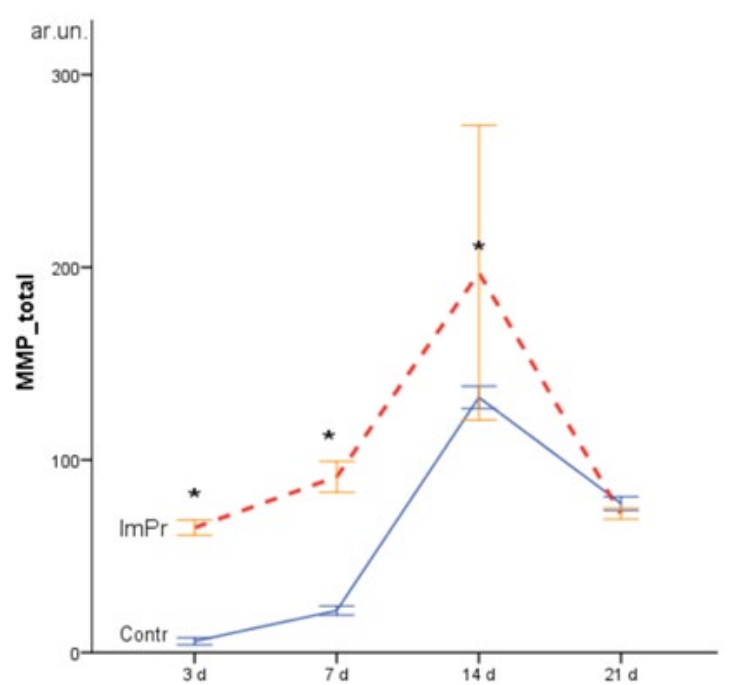

C

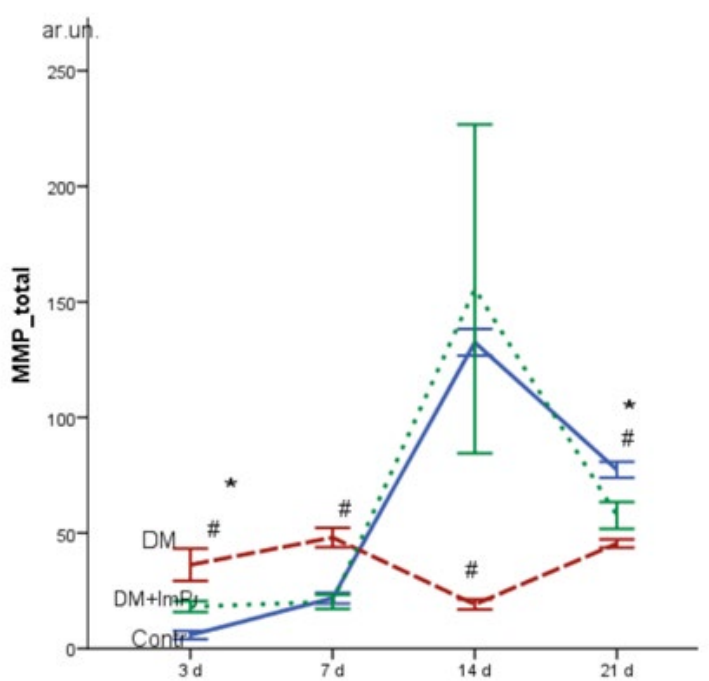

$\boldsymbol{B}$

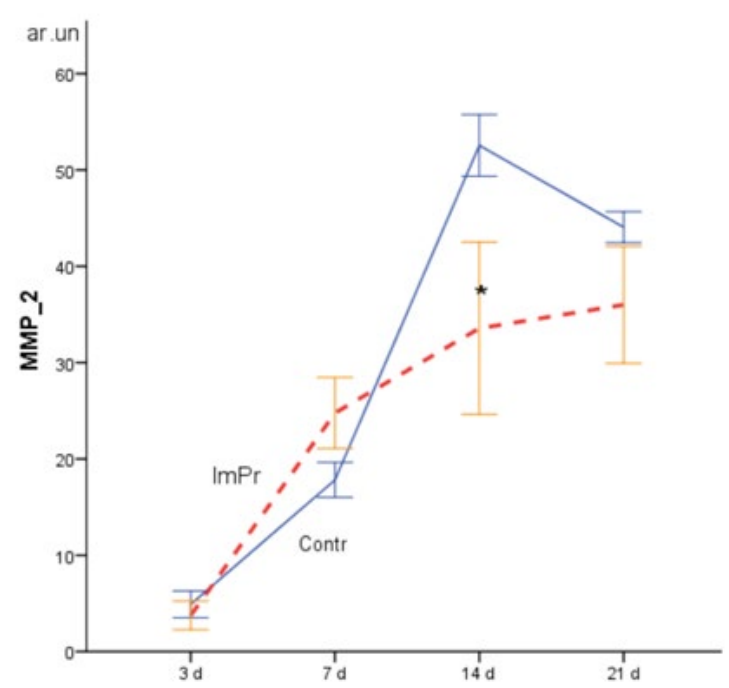

$\boldsymbol{D}$

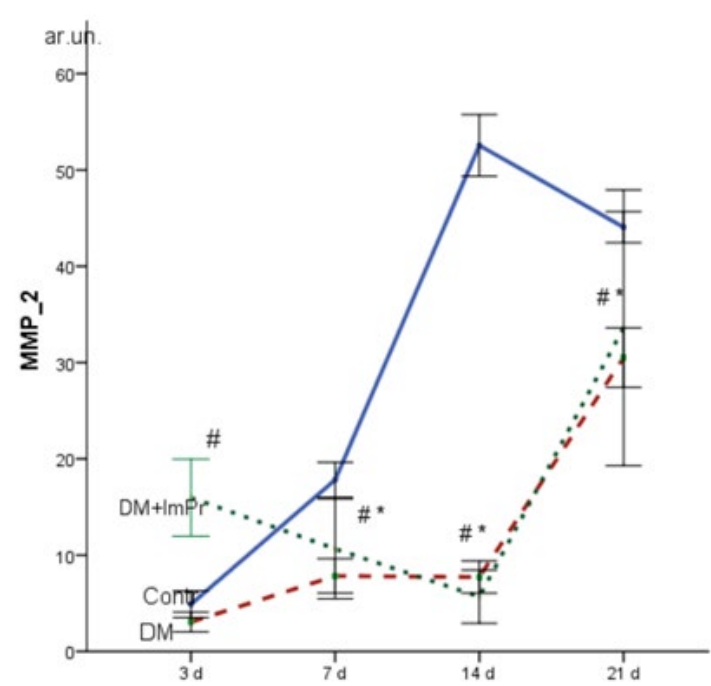

Fig. 3. The level of matrix metalloproteinases in regenerating skin tissue of rats in the dynamics of burn wound healing. (A, B) MMP total and MMP-2 - at physiological healing process (Contr) and under the influence of exogenous immobilized proteases (ImPr). (C, D) MMP total and MMP-2 in animals with experimental diabetes mellitus (DM) and under the influence of exogenous immobilized enzymes at physiological healing process in animals with diabetes mellitus $(\mathrm{DM}+\mathrm{ImPr}) .{ }^{*} \mathrm{p} \leq 0.05$, if compare $\mathrm{DM}$ to Control group, $\# \mathrm{p} \leq 0.05$, if compare $\mathrm{DM}+\operatorname{ImPr}$ to Control group 

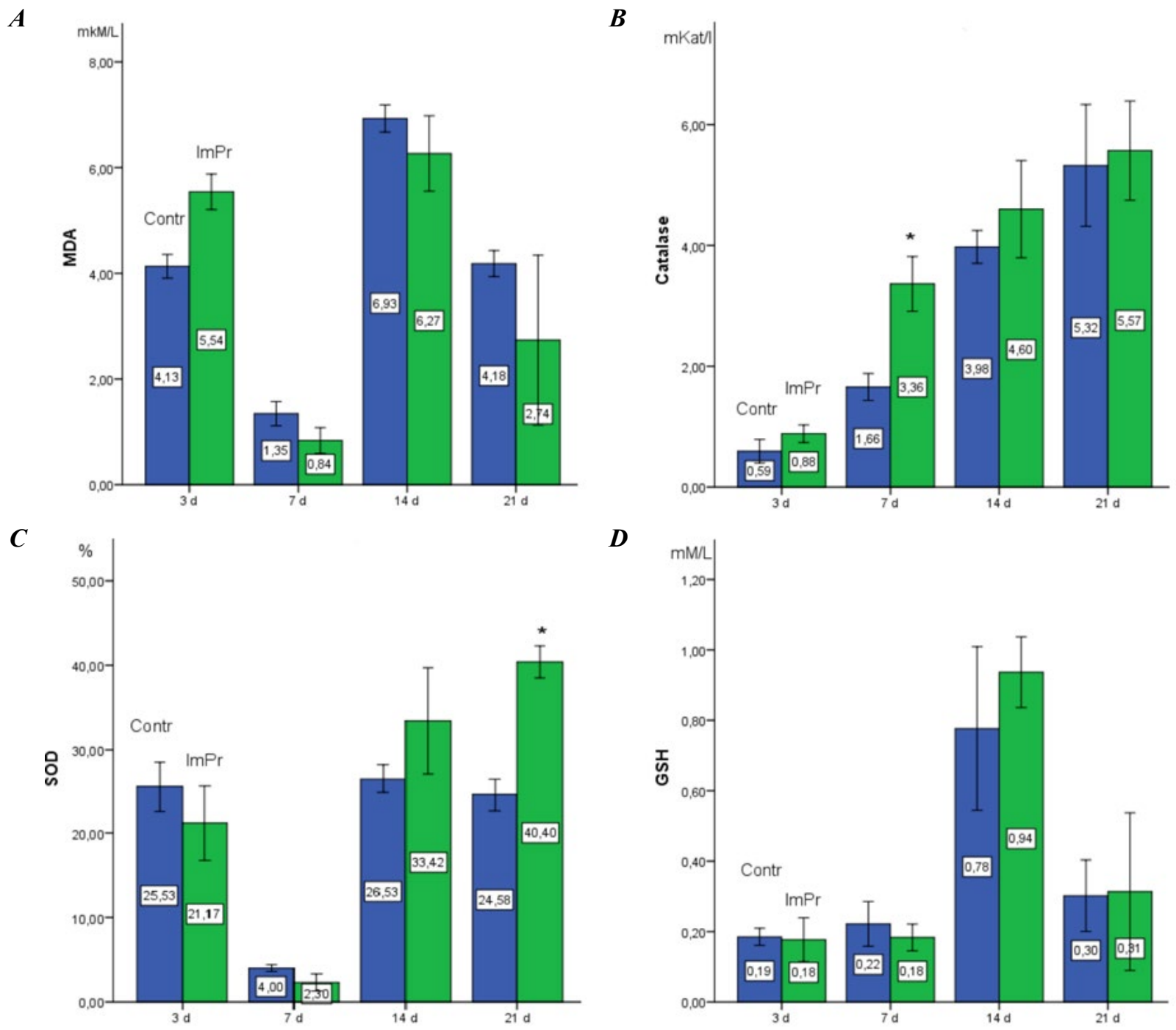

Fig. 4. Level of oxidative stress indicators and antioxidant system: MDA (A), catalase (B), SOD (C), GSH (D) in regenerating skin tissue of rats in the dynamics of burn wound healing - at physiological healing process (Contr) and under the influence of exogenous immobilized proteases (ImPr). ${ }^{*} \mathrm{p} \leq 0.05$, compared to Control group.

further decrease on day 21. The application of the composition did not significantly affect the indicator.

The wound healing in diabetic animals had some macroscopic features (Fig. 1) [18]. On day 7 of the experiment, the burn area was covered with a scab of uneven thickness. The areas with scab rejection and purulent exudate were observed on day 14 . Under the scab, a wide layer of immature connective tissue with signs of delayed epithelialization was observed. On day 21 , destructive changes in 

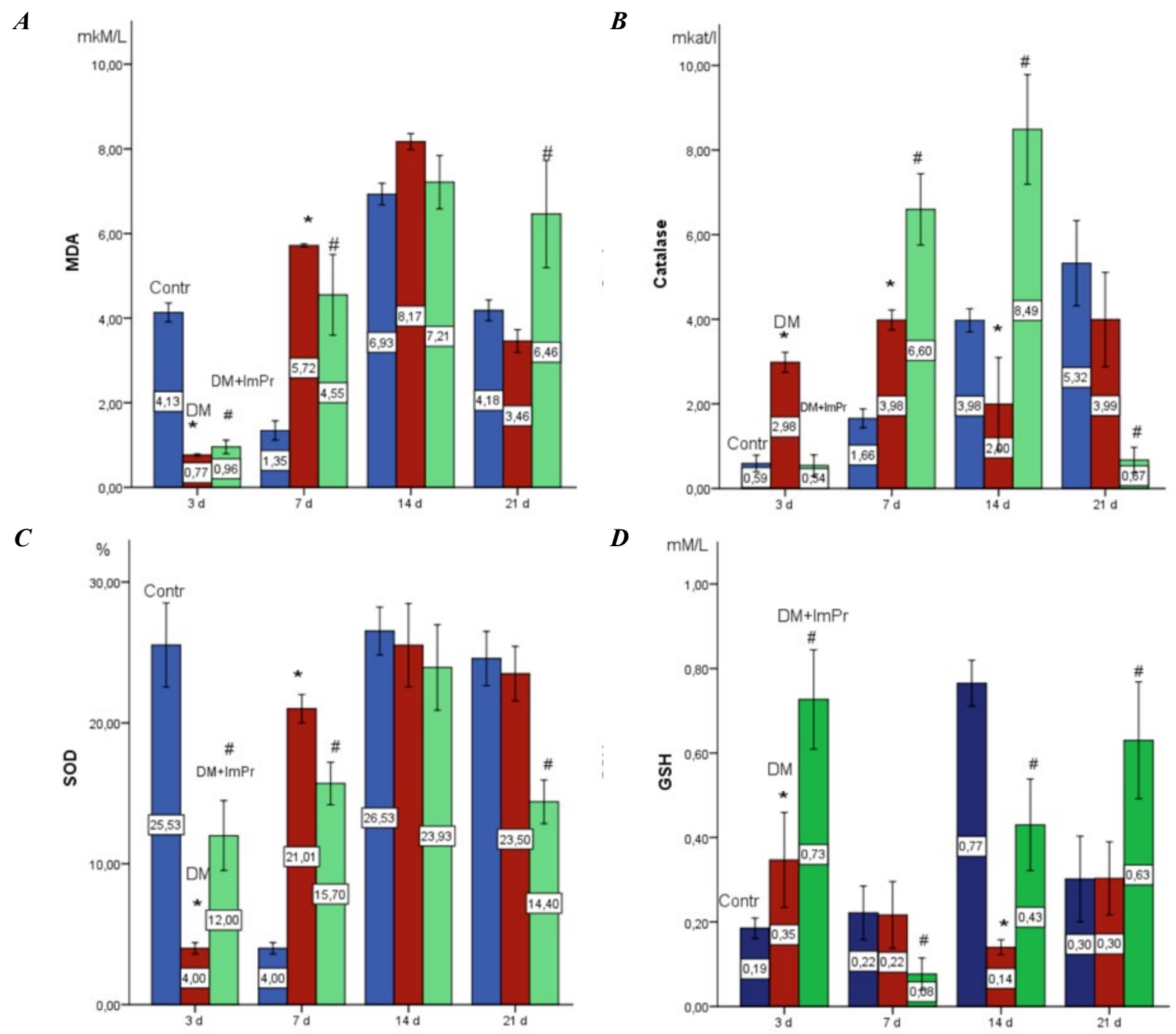

Fig. 5. Level of oxidative stress indicators and antioxidant system: MDA (A), catalase (B), SOD (C), GSH (D) in regenerating skin tissue of rats in the dynamic[s] of burn wound healing — at physiological healing process (Contr), in animals with experimental diabetes mellitus (DM) and under the influence of exogenous immobilized enzymes in animals with diabetes mellitus $(\mathrm{DM}+\operatorname{ImPr}){ }^{*} \mathrm{p} \leq 0.05$, if compare $\mathrm{DM}$ to Control group, $\# \mathrm{p} \leq 0.05$, if compare $\mathrm{DM}+\mathrm{ImPr}$ to Control group.

epidermis and underlying tissues were detected. The affected zone was almost completely devoid of epidermal lining, except for peripheral regions.
The use of enzyme-containing composition in diabetic animals showed a visual improvement of wound healing. Zones of purulent exudate and destruction of epidermis were 
practically absent by the $14^{\text {th }}$ day. The epithelialization islands were observed in $\mathrm{DM}+\mathrm{ImPr}$ group on day 21 .

In DM, MMP_total content remained low throughout the healing period, which is a reflection of general hyporeactivity of tissues in case of DM. The use of the composition increased total MMPs level during the 14-21 days period, which corresponded to the physiological scenario of healing process (Fig. 2). It also completely coincided with an increase of SOD activity in this period of time (Fig. 5). Activation of MMPs by free radicals is a direct effect of superoxide on allosteric center of enzymes and a result of the transcription factor NF- $\mathrm{KB}$ activation that increases the MMPs genes expression [11].

MMP_2 level did not show any connection with the application of the composition. The difference between DM+ImPr and DM groups was observed only on day 3 : it was 5-fold increase in $\mathrm{DM}+\operatorname{ImPr}$ group $(\mathrm{p}<0.01)$. The indicators did not significantly differ between DM and Contr group.

Under the influence of the composition, the indicators of oxidative homeostasis (Fig.4) varied in different directions in diabetic animals. In DM group, there were 5-fold decrease of $\boldsymbol{M D A}$ level on day 3 and 5-fold increase on day 7 of observation $(\mathrm{p}<0.01)$, compared to Contr group. The application of the composition contributed to the reduction of MDA in $\mathrm{DM}+\mathrm{ImPr}$ group, but only in period of 7-14 days. On day 21, MDA level in DM+ImPr group was $1.5-2$ times higher $(p<0.01)$ compared to Contr and DM groups.

The level of catalase in diabetic wound healing was not significantly changing during all periods of observation. The application of the composition increased the catalase activity up to 10-12 times $(p<0.01)$, but this effect was observed only on days 7 and 14 with a sharp decrease on day 21.

The $\boldsymbol{S O D}$ level in DM sharply decreased up to 8 times $(\mathrm{p}<0.01)$ on day 3 and increased up to 5 times $(p<0.01)$ on day 7 , compared to Contr group. The application of the composition contributed to gradual increase of SOD level from day 3 to 14 with further decrease on day 21. The level of glutathione in DM group was the lowest on day $14(p<0.01)$. Application of the composition increased the level of glutathione on days 3 and 21 up to 3.8 and 2 times, respectively $(\mathrm{p}<0.01)$, and decreased up to 2 times on days 7 and $14(\mathrm{p}<0.01)$, compared to Contr group.

\section{Discussion}

In case of physiological wound healing, the application of exogenous proteases caused an increase of total MMPs level in all periods of observation. Excessive proteolysis of ECM proteins leads to additional tissue damage because of TLR-receptors activation on leukocytes [19] and increased production of free radicals (compared to control group). At the same time, the activity of antioxidant system increases to compensate the tissue damage by ROS: catalase, glutathione and SOD levels were elevated on days 7, 14 and 21, respectively $[11,17]$.

However, application of the composition leads to decreased MMP-2 level on days 1421 , which, in our opinion, reduces neovascularization of the wound because MMP-2 triggers the release of growth factors required for angiogenesis and re-epithelialization in physiological conditions [19]. According to our 
previous study, the regenerate tissue undergoes the process of active vessel formation due to increasing bioavailability of vessel endothelial growth factor (VEGF) during this period of healing process [20]. Therefore, the application of the composition cannot be considered as a positive effect for skin burns healing in rats without somatic pathology.

Meanwhile, the content of total MMPs in the wound remained low throughout the all periods of healing in rats with DM, but exceeded the levels in control group on days 3 and 7 . The MMP-2 level was also significantly reduced on days 3-14, which corresponded to the previously obtained results [21]. It can be explained by dysfunction of fibroblasts and redundant glycation of ECM proteins. It makes these proteins more stable to proteolytic degradation and they can even induce fibroblast apoptosis via activation of RAGE (receptors for AGEs) [22]. This condition makes impossible the formation of a full-fledged granulation tissue. So, application of the enzymecontaining composition can play protective role and improve wound healing by increasing proteolysis of ECM proteins.

In our previous work, we studied cell composition and activity of energy processes in tissue during wound healing in DM, taking into consideration that the metabolism changes affect reprogramming of macrophages functional phenotype (transitiom from M1 to M2). Pronounced and multidirectional changes in the activity of redox enzymes of macrophages in different phases of reparation process were revealed. In DM, an increased activity of macrophages by the $21^{\text {th }}$ day was related to the inappropriate and excessive activity of MMPs and other proteolytic enzymes as a response to the products of ECM degradation, which is one of the causes of chronic inflammation [18].

The composition use in diabetic animals increased the level of total MMPs on day 14, which corresponded to the physiological healing scenario. Furthermore, an increased level of total MMPs correlated with an increased activity of catalase on day 14 . Catalase reduces the level of hydrogen peroxide and decreases tissue damage by ROS that serves as an additional signal for neoangiogenesis. According to our data, expression of VEGF increases in the tissue regenerate during this period [20].

When applying the composition in animals with DM, the MDA level shows that the oxidative load decreased during the first 20 days. The oxidative protection indicators were increasing: catalase level by the $7-14^{\text {th }}$ days and glutathione level on days 3 and 21 . It can be considered as a positive effect, because it enhances the tissue antioxidation. Thus, the application of the composition significantly changed the activation of total MMPs in the regenerate, and did not worsen the state of oxidative homeostasis in the wound.

\section{Conclusion}

Local application of the exogenous proteases composition is appropriate only to enhance and control proteolysis in chronic hyperglycemia under condition of the glycated proteins predominance in tissue.

\section{Acknowledgements}

The authors would like to thank A.O. Tyhomyrov, PhD, Palladin Institute of Biochemistry, NASU, for help in conducting zymography for MMPs assessment. 


\section{Funding information}

The work was funded by Ministry of Public Health of Ukraine. Grant No 0119U101219.

\section{REFERENCES}

1. Kateel R, Augustine AJ, Prabhu S, Ullal S, Pai M, Adhikari $P$. Clinical and microbiological profile of diabetic foot ulcer patients in a tertiary care hospital. Diabetes Metab Syndr. 2018;12(1):27-30.

2. Boulton AJM. The diabetic foot. Medicine. 2018;47(2):100-5.

3. Davis FM, Kimball A, Boniakowski A, Gallagher K. Dysfunctional Wound Healing in Diabetic Foot U1cers: New Crossroads. Curr Diab Rep. 2018;18(1):2.

4. Reinke JM, Sorg H. Wound repair and regeneration. Eur Surg Res. 2012;49(1):35-43.

5. Singh K, Agrawal NK, Gupta SK, Mohan G, Chaturvedi S, Singh K. Differential Expression of Matrix Metalloproteinase-9 Gene in Wounds of Type 2 Diabetes Mellitus Cases With Susceptible $-1562 \mathrm{C}>\mathrm{T}$ Genotypes and Wound Severity. Int $J$ Low Extrem Wounds. 2014;13(2):94-102.

6. Lobmann R, Ambrosch A, Schultz G, Waldmann $K$, Schiweck $S$, Lehnert $H$. Expression of matrix-metalloproteinases and their inhibitors in the wounds of diabetic and non-diabetic patients. Diabetologia. 2002;45(7):1011-6.

7. Stevens LJ, Page-McCaw A. A secreted MMP is required for reepithelialization during wound healing. Mol Biol Cell. 2012;23(6):1068-79.

8. Enoch S, Grey JE, Harding KG. ABC of wound healing. Non-surgical and drug treatments. BMJ. 2006;332(7546):900-3.

9. Sabino F, auf dem Keller $U$. Matrix metalloproteinases in impaired wound healing. Metalloproteinases in Medicine. 2015; 2:1-8.

10. Mirastschijski U, Haaksma CJ, Tomasek JJ, Agren MS. Matrix metalloproteinase inhibitor GM 6001 attenuates keratinocyte migration, contraction and myofibroblast formation in skin wounds. Exp Cell Res. 2004;299(2):465-75.

11. Xue M, March L, Sambrook PN, Jackson CJ. Differential regulation of matrix metalloproteinase 2 and matrix metalloproteinase 9 by activated protein $\mathrm{C}$ : relevance to inflammation in rheumatoid arthritis. Arthritis Rheum. 2007;56(9):2864-74.

12. Borşa C, Grădinaru D, Ionescu C, Pena CM, Prada GI. Glycoxidative stress in aging and pathology. Rom J Gerontol Geriatr. 2018; 7(1):32-8.

13. Verevka $S V$. Kompozytsiyadlyazahoyennya ran Zayavka U 201508389 vid 26.08.2015. Patent nakorysnu model' N 105500 vid 25.03.2016, Byul. № 6 vid 25.03.2016. A 62 K 38/4 (2006.01).

14. Sweeney PJ, Walker JM. Pronase (EC 3.4.24.4). Methods Mol Biol. 1993;16:271-6.

15. Yamskov IA, Tichonova TV, Davankov VA. Pronasecatalyzed hydrolysis of amino acid amides. Enzyme Microb Technol. 1986; 8(4):241-4.

16. Snoek-van Beurden PA, Von den Hoff JW. Zymographic techniques for the analysis of matrix metalloproteinases and their inhibitors. Biotechniques. 2005;38(1):73-83.

17. Fukai T, Ushio-Fukai M. Superoxide dismutases: role in redox signaling, vascular function, and diseases. Antioxid Redox Signal. 2011;15(6):1583-606.

18. Natrus LV, Verko NP, Ryzhko IM, Panova TI, Osadchuk YS. The dynamic of the energy metabolism of the cells of white rats skin connective tissue under the conditions of the burn injury and hyperglycemia. Medical Science of Ukraine. 2019; 14(1-2):3-10.

19. Banerjee P, Suguna L, Shanthi $C$. Wound healing activity of a collagen-derived cryptic peptide. Amino Acids. 2015;47:317-28.

20. Natrus LV, Myronenko OI, Panova TI. Peculiarities

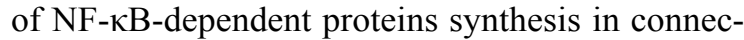
tion tissue at the remodeling stage of burn wound healing. East European Scientific Journal. 2019; 50(3):40-7.

21. Wall SJ, Bevan D, Thomas DW, Harding KG, Edwards DR, Murphy $G$. Differential expression of matrix metalloproteinases during impaired wound healing of the diabetes mouse. J Invest Dermatol. 2002;119(1):91-8.

22. Briquez PS, Hubbell JA, Martino MM. Extracellular Matrix-Inspired Growth Factor Delivery Systems for Skin Wound Healing. Adv Wound Care (New Rochelle). 2015;4(8):479-489. 


\section{Вплив мікробних протеаз на активність матриксних металопротеїназ та показники окисного стресу ранової тканини щурів з експериментальним цукровим діабетом \\ О. І. Мироненко, Л. В. Натрус, Т. І. Панова, С. В. Верьовка}

Мета. Вивчити вплив мікробних протеаз на активність матриксних металопротеїназ та показники окисного стресу ранової тканини щурів з експериментальним цукровим діабетом (ЦД). Методи. Опік шкіри моделювали тваринам без соматичної патології та на тлі ЦД, що відтворювали однократним введенням стрептозотоцину, 50 мг/кг. На рану наносили мультиферментний протеолітичний комплекс Pronase (SigmaAldrich, USA), отриманий з культуральної рідини Streptomiceus griseus. Вміст малонового діальдегіду (MDA), активність каталази (CAT), супероксид дисмутази (SOD), глутатіону (GSH) вимірювали на спектрофотометрі. Колагенолітичну активність матриксних металопротеїназ (MMPs) тканин шкіри визначали методом ензим-форезу (желатинова зимографія). Результати. При фізіологічному загоєнні рани нанесення досліджуваної композиції підвищувало активність загальних MMPs в гомогенаті у 3-14 добу загоєння, що посилювало утворення вільних радикалів та активність системи антиоксидації: САТ на 7 добу, GSH на 14 та SOD на 21 - для компенсації ушкодження тканини. На тлі ЦД застосування композиту збільшувало активність MMPs у 14-21 добу, що поліпшувало протеолітичну деградацію білків позаклітинного матриксу в стані надлишкового глікозилювання і не погіршувало стан окисного гомеостазу в рані. Висновки. Застосування препаратів екзогенних протеаз $є$ доцільним для підсилення протеолізу, за умов переважання в тканинах глікірованих протеїнів на тлі гіперглікемії для забезпечення контрольованого протеолізу.

К л юч о в i с л о в а: Стрептозотоцин-індукований діабет, опіковарана, окисний стрес, протеоліз, загоєння.

\section{Влияние микробных протеаз на активность матриксных металлопротеиназ и показатели оксидативного стресса в раневой ткани крыс с экспериментальным сахарным диабетом \\ О. И. Мироненко, Л. В. Натрус, Т. И. Панова, С. В. Верёвка}

Цель. Влияние микробных протеаз на активность матриксных металлопротеиназ и показатели оксидативного стресса в раневой ткани крыс с экспериментальным сахарным диабетом (СД). Методы. Ожог кожи моделировали у животных без соматической патологии и на фоне СД, который воспроизводили путём однократного введения стрептозотоцина, 50 мг/кг. На рану наносили мультиферментный протеолитический комплекс Pronase (Sigma-Aldrich, USA), полученный из культуральной жидкости Streptomiceus griseus. Содержание малонового диальдегида (MDA), активность каталазы (CAT), супероксиддисмутазы (SOD), глутатиона (GSH) измеряли на спектрофотометре. Коллагенолитическую активность матриксных металлопротеиназ (MMPs) ткани кожи определяли методом энзим-фореза (желатиновая зимография).Результаты. При физиологическом заживлении раны нанесение исследуемой композиции повышало активность общих MMPs в гомогенате на 3-14 сутки заживления, что усиливало образование свободных радикалов и активность системы антиоксидации: CAT на 7, GSH на 14 и SOD на 21 сутки - для компенсации повреждения тканей. На фоне СД применение композиции увеличивало активность MMPs на 14-21 сутки, что улучшало протеолитическую деградацию белков внеклеточного матрикса в состоянии избыточного гликозилирования и не ухудшало состояние оксидативного гомеостаза в ране. Выводы. Применение препаратов экзогенных протеаз является целесообразным для усиления протеолиза при условии преобладания в ткани гликозилированных протеинов на фоне гипергликемии для обеспечения контролируемого протеолиза.

Кл юч е в ы е с л о в а: Стрептозотоцин-индуцированный диабет, ожоговая рана, оксидативный стресс, протеолиз, заживление. 